\title{
The Traditional Knowledge of Wild Edible Leaf used by Tribal People in Chhattisgarh
}

\author{
Babita Kumari ${ }^{1}$, Hitesh Solanki ${ }^{2}$
}

DOI: 10.18811/ijpen.v5i04.9

\begin{abstract}
Chhattisgarh, A state of rich biodiversity zone covered a wide range of forest having three climatic zones namely north and central eastern plateau zone, Eastern plateau zone, Western plateau zone supporting a rich biodiversity. Approximately, 30 tribal inhabitants depend on forest for survival and population live below the poverty line. The forest provide a significant role to provide them wild leafy vegetables, consumed by the tribal and other local inhabitants. These wild edible leaves not only provide the nutritional requirements of local population but ensure food security for the people living in and around forests areas. The role of present study was to enthuses the various wild edible leaves eaten by the local communities.
\end{abstract}

Keywords: Food security, Nutrition, Tribal Community, Wild leafy vegetables.

International Journal of Plant and Environment (2019);

ISSN: 2454-1117 (Print), 2455-202X (Online)

\section{INTRODUCTION}

T he human population has used leaves as food since decades. The different types of leaves depending from the place and the season were a part of the human diet since prehistoric times. According to many historians, Traces of edible leaves have been found in ancient Egyptian archaeological sites. Many edible leaves were historically documented since ancient Greece, in ancient Rome, in ancient Sri Lanka and in the middle Ages. Eventually, the passing of the centuries might have traditional leaf vegetables have been replaced by leaves (Chauhan et al., 2014). The different wild Leaves are the gift of nature to the tribal people throughout the year which supplement their nutritional requirements. Interestingly, the wild green leaves play a significant role as primary food because they have a high vitamin $\mathrm{K}$ and food value in comparison to other fruit and vegetables. They are also rich source of minerals like iron, calcium, potassium and magnesium (Mishra and Mishra, 2013). The State of Chhattisgarh is not only a forest of natural rich state but also has a rich availability of wild edible leaves (Chowdhury and Mukherjee, 2012). It shows the poor situation of consumption of all the specific food items except green leaves (Cooper et al., 1966). Due to presence of rich Biodiversity, Chhattisgarh state plays a significant role in food and nutritional security of the tribal inhabitants. The consumption of leafy vegetable not only provide food quantity but also enhance the population nutrition throughout the year (Grivetti and Ogle, 2000; Ogle, 2001; Ogle et al., 2001, 2003). Normally the tribal inhabitants earn their livelihood by selling these nutritious leafy vegetables and contribute to household food security.

Pendra road is a forest region, which is situated in Northern region of Bilaspur district of Chhattisgarh state. The climatic condition of district is sub humid type. Average rainfall is $52.8 \mathrm{~mm} /$ year. Edible wild plants are an important source of food of tribes in this region. Tribal Population of Pendra road is approximately $25-30 \%$. Fifty six species of wild plants were used by inhibited tribal's and villagers for food. Among those species 21 species are herb, belonging to 21 Genera, and 15 families, followed by 10 species are shrub, belonging to 10 Genera and 10 families and 17 species are trees belonging to 15 Genera and 12 families. 07 species are climber in nature belonging to 05 Genera and 05 families documented plants 16 were abundant 24 were common and 15 were uncommon in this area. Total number of genera and species
${ }^{1}$ Faculty of Sciences, Indira Gandhi Technology and Medical Sciences University, Ziro, Arunachal Pradesh, INDIA

${ }^{2}$ Department of Botany, Gujarat University, Ahmadabad, Gujarat, INDIA

Corresponding Author: Dr. Babita Kumari, Faculty of Sciences, Indira Gandhi Technology and Medical Sciences University, Ziro, Arunachal Pradesh, India, Mobile: +91-9315055206, Email: bbtmshr@yahoo.co.in

How to cite this article: Kumari, B. and Solanki, H. (2019). The Traditional Knowledge of Wild Edible Leaf used by Tribal People in Chhattisgarh. International Journal of Plant and Environment 5(4): 284-292

\section{Source of support: Nil}

Conflict of interest: None

Submitted:22.07.2019 Accepted:01.10.2019 Published:31.10.2019

are calculated (Ahirwar and Shakya, 2013; Ekka and Ekka, 2016; Sharma and Sharma, 2017).

In an another study in Bhoramdeo Wild life sanctuary three villages filed survey Thuhapani, Pahchrahi, and Bairkh, Kabirdham region of India. Chhattisgarh to document the diversity, indigenous uses and availability status of edible plants. The tribes of this region are dependent up to a large extent on wild resources for their food and other daily needs. Plant parts such as leaves, shoots, young twigs, roots, rhizomes, tubers, flowers, fruits, seeds, etc. are used for food by the tribal people. plant species were recorded which are being used as vegetables, drinks, fruits, dry fruits, pickles, foods, chutney, confection and curry. Lal et al. (2017) identifies 115 edible plant species under 108 genera and 45 families. They recorded species 59 were herbs, 09 shrubs, 29 trees and the rest 18 were climbers.

\section{Methodology}

The present study has been conducted within Chhattisgarh state looking food supplement of poor people covers an area of 8,537 $\mathrm{km}^{2}$. The gross population rate in 2006 was 2,997,100, out of which $30 \%$ were scheduled tribes. A regular survey alongwith local market and village of different district have been surveyed in the year 2016-2018. The state has been diversified into different climatic zones on the basis of the heterogeneity of soil type, topography, and atmospheric weather. The identified and collected plant 

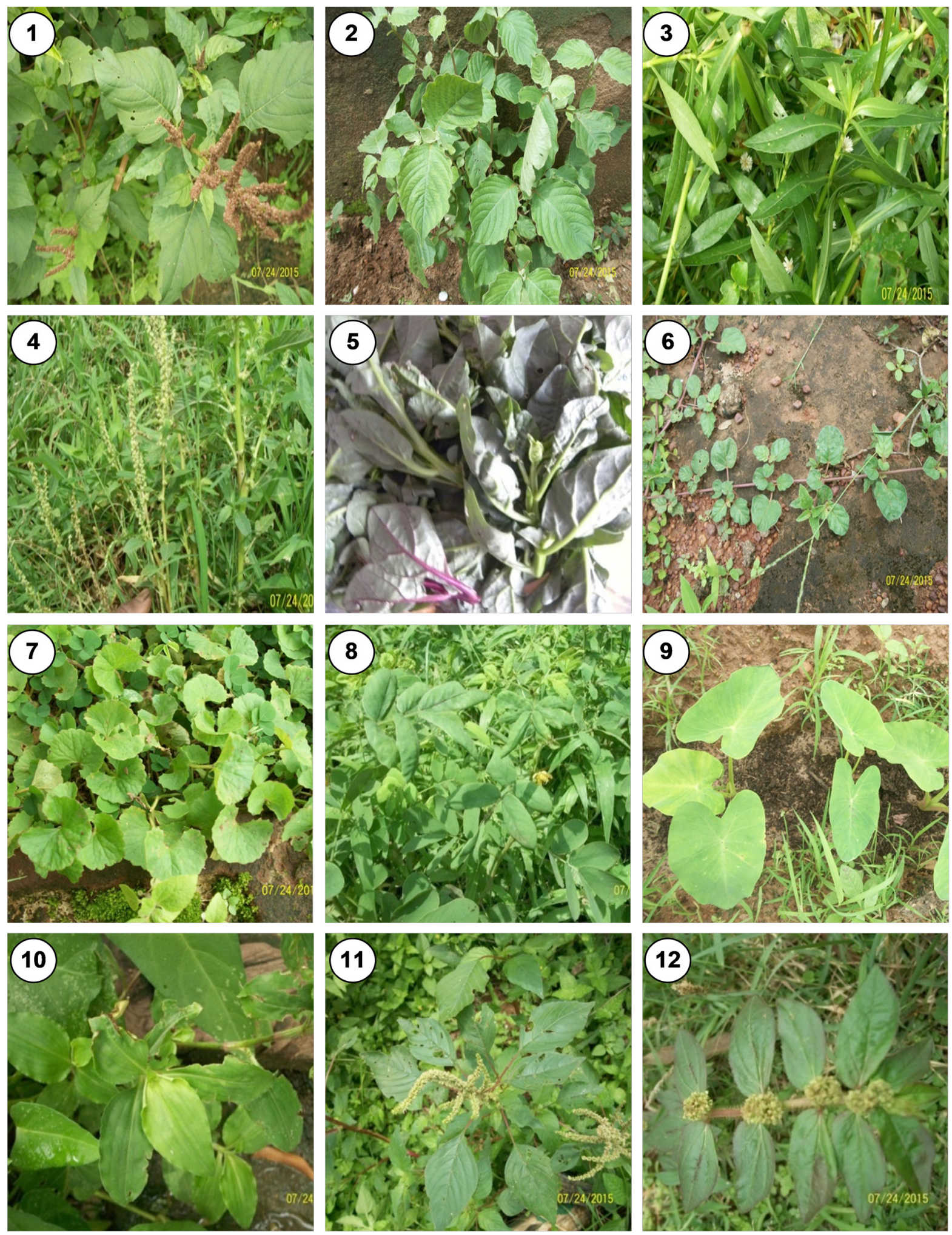

Plate 1: Photograph of some wild edible leaves. 1. Amaranthus viridis, 2. Alternantha philoxiroids, 3. Achyranthus aspera, 4.Amaranthus spinosus, 5. Basella rubra, 6. Centella asiatica, 7. Centella asiatica, 8. Cassia tora, 9. Colocasia esculenta, 10. Commelina begalensis, 11. Chenopodium album, 12. Euphorbia hirta, 13. Oxalis corniculata, 14. Ipomoea aquatic, 15. Moringa oleifera, 16. Vanguira spinosa, 17. Alternanthera sessilis, 18. Azadirachta indica, 19. Bauhinia retusa, 20. Albesmuscus cannabinacus, 21. Antidesma diandrum, 22. Portulacaoleracea, 23. Oxalis corymbosa, 24. Marsilia minuta, 25. Monochoria vaginalis, 26. Mentha piperta, 27. Mentha spicata, 28. Hygrophila auriculata, 29. Eryngium foetidum, 30. Polygonum plebejum, 31. Limnophila confirta, 32. Piper longum, 33. Cordia dichotoma, 34. Celosia argentea, 35. Tamarindus indica, 36. Ficus infectoria, 37. Dry leaves sold out in market, 38. Survey with tribals. 

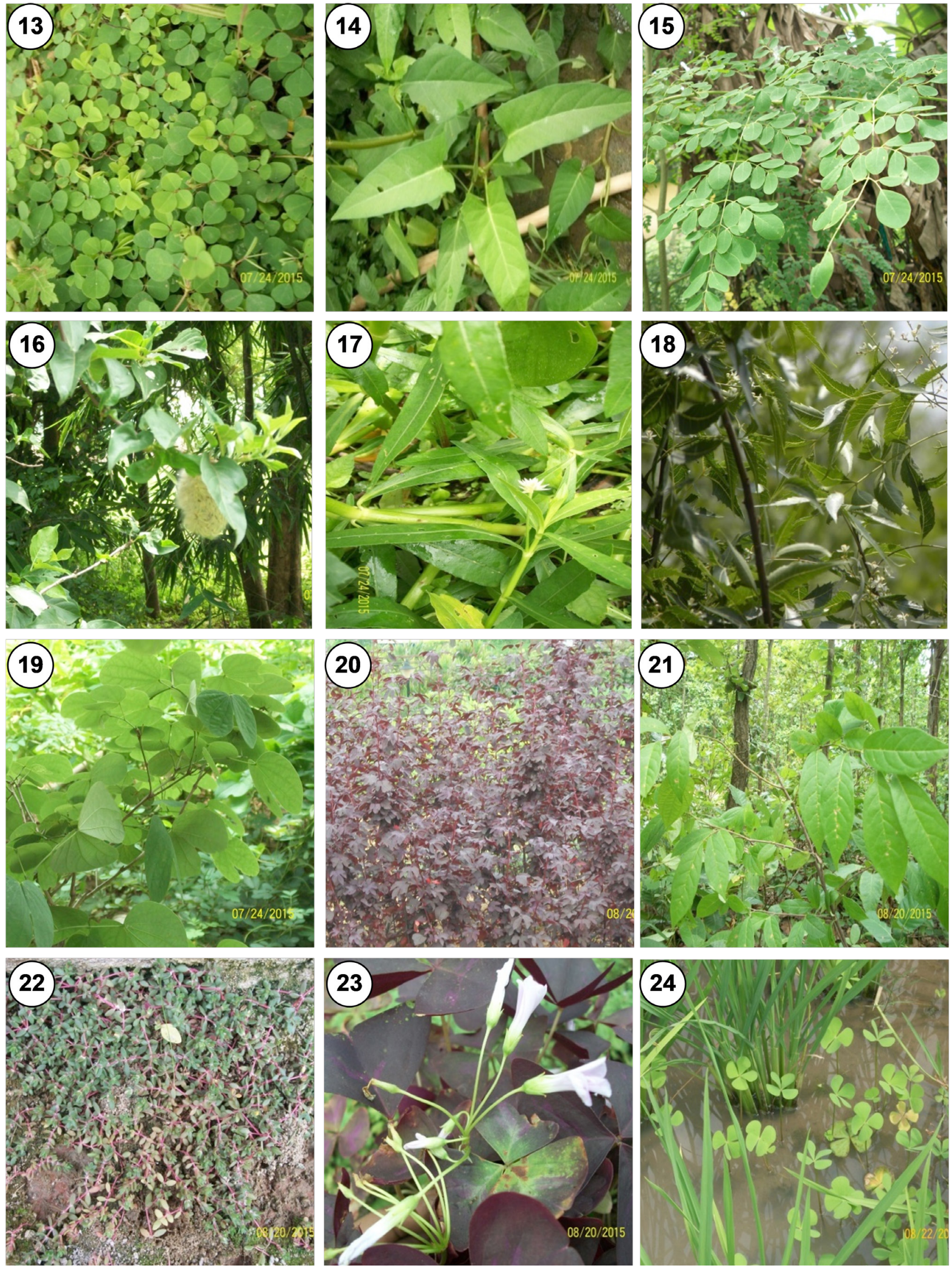

Plate 1 continued 

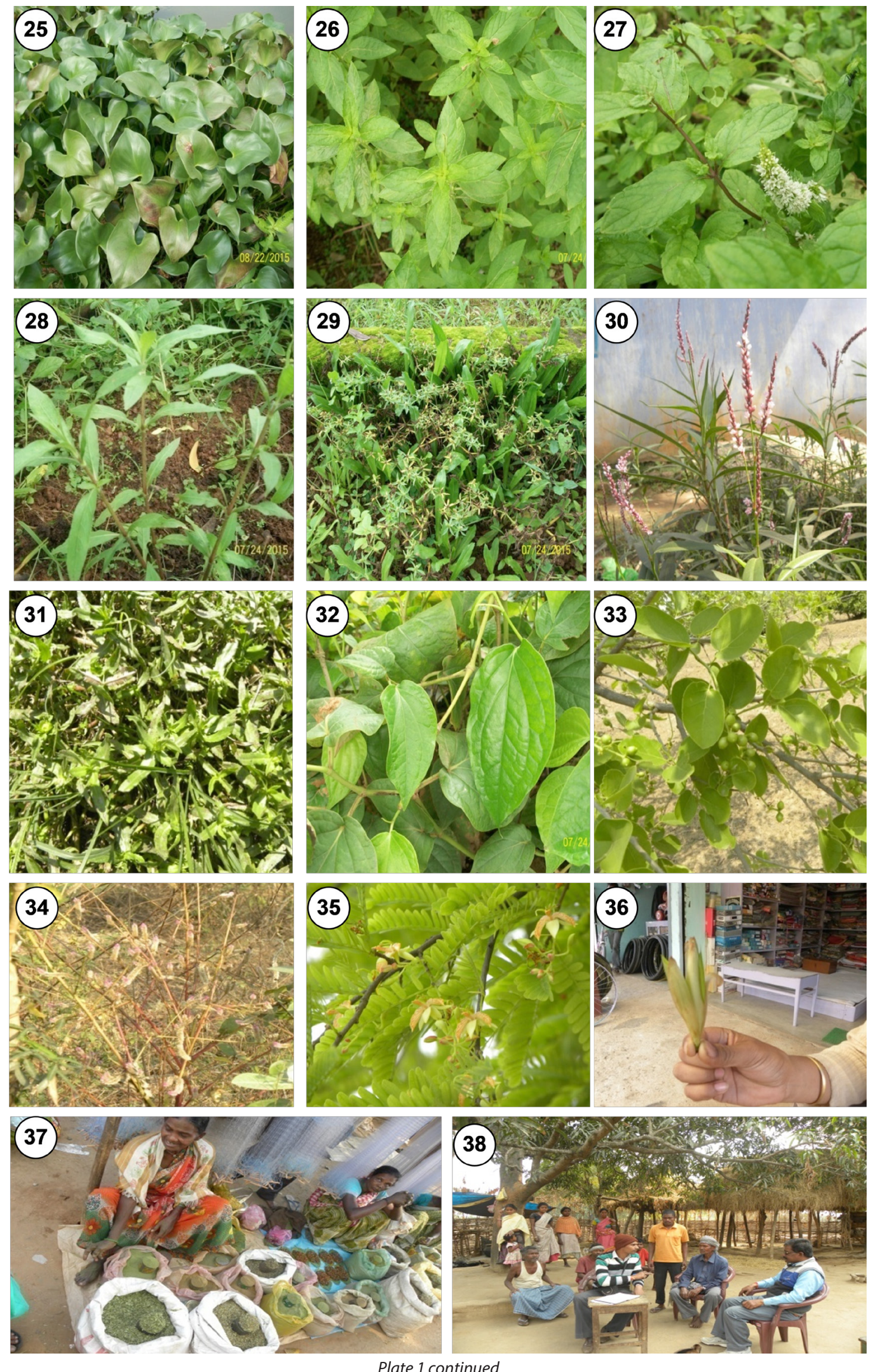

Plate 1 continued 


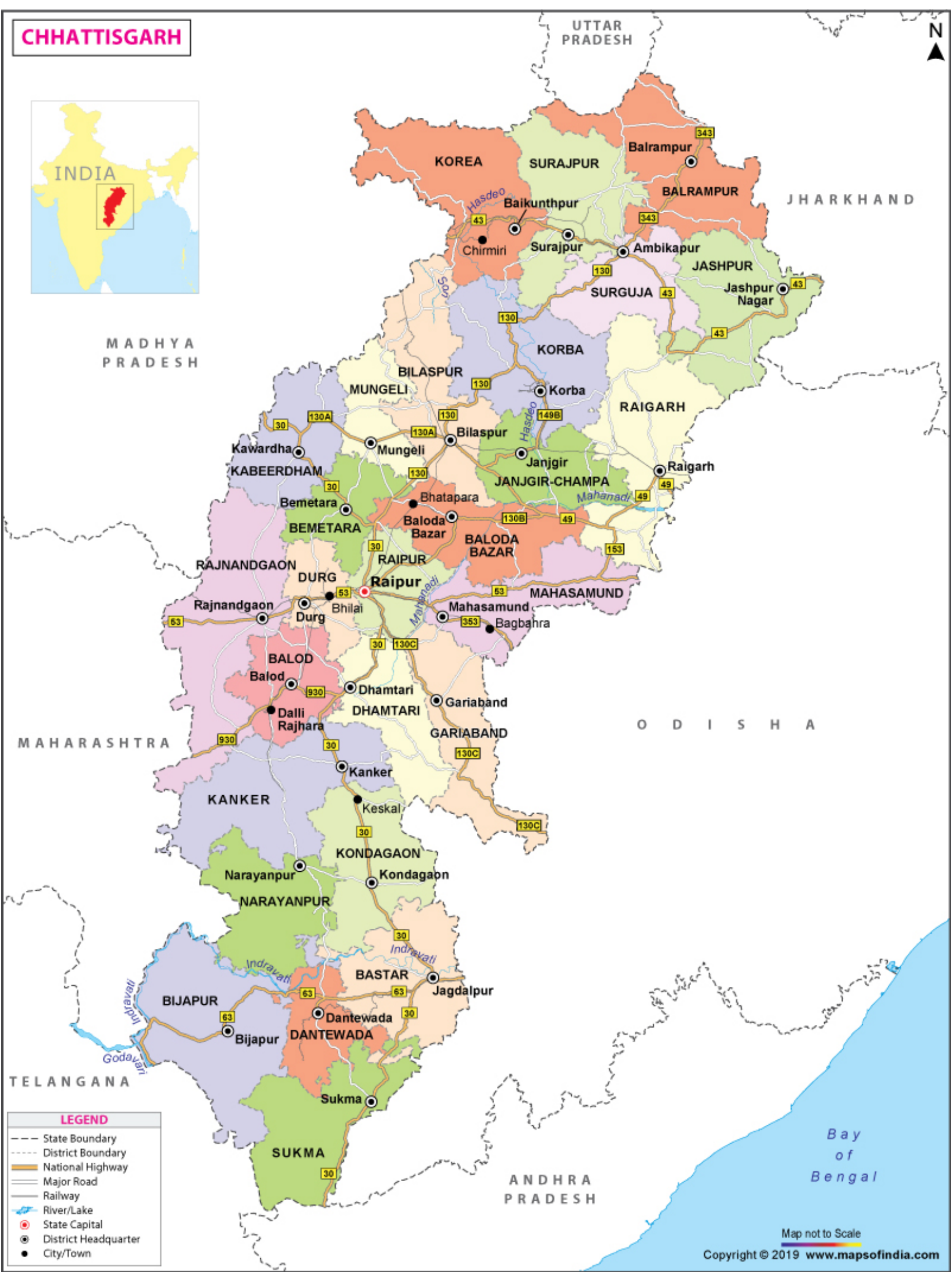

Fig. 1: Map showing adjacent parts of sample collection in Chhattishgarh. 


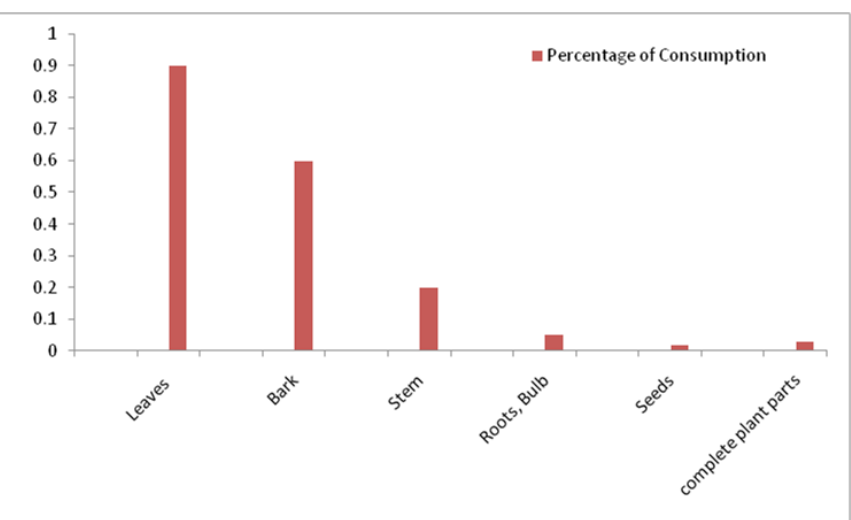

Fig. 2: The consumption of plant parts by the tribes and local people of Chhattisgarh. samples were arranged and documented according to their local names.

\section{Result and Discussion}

India has approximately 900 species, are consumed as wild edible plants by the tribal people. This study pertains to only the wild edible leaves consumed by the tribal and local communities of Chhattisgarh state. The total respondents were 20-22 in numbers per villages to collect sample of leafy vegetables which were identified from forest department (Fig. 1). In this study, it was found that the plant belonging to Amaranthaceae is a vigorous, erect, perennial, branched growing to $10-100 \mathrm{~cm}$ tall. The plant is often harvested from the wild as a source of food and medicines. It is sometimes cultivated in the Tropics for its edible leaves and is often sold in local markets (Plate 1). In Mimosaceae, The leaves

Table 1: Some wild edible plants parts with their consumption in Chhattisgarh.

\begin{tabular}{|c|c|c|c|c|c|}
\hline S.N. & Botanical name & Family & Vernacularnames & Part consumed & Method of consumption \\
\hline 1 & Achyranthus aspera L. & Amaranthaceae & Chirchithi & Leaves & Fresh leaves cooked \\
\hline 2 & Adathoda vasica & & Bakas & Leaves & Fresh leaves \\
\hline 3 & Adenanthera pavoniana $\mathrm{L}$. & Mimosaceae & Rakht kanchan & Leaves & Dry leaves \\
\hline 4 & Aerva lantana Juss. & Amaranthaceae & Lopong Sag & Leaves & As vegetable \\
\hline 5 & Alternanthera philoxiroids $\mathrm{Br}$. & Amaranthaceae & Garundi & Young plant & Fried/Roasted \\
\hline 6 & Alternanthera pungens Kunth. & Amaranthaceae & Guri bhaji & Leaves & As vegetable \\
\hline 7 & Alternanthera sessilis $\mathrm{Br}$. & Amaranthaceae & Saronchi & Young plant & Fried/Roasted \\
\hline 8 & Amaranthus gangeticus Roxb. & Amaranthaceae & Lal sag & Leaves & Fresh leaves are cooked \\
\hline 9 & Amaranthus spinosus Linn. & Amaranthaceae & Kanteli Chaulai & Leaf shoot & Leaves cooked \\
\hline 10 & Amaranthus viridis Linn. & Amaranthaceae & $\begin{array}{l}\text { Bhaji sag, Lotia } \\
\text { sag }\end{array}$ & $\begin{array}{l}\text { Leaf and } \\
\text { shoot }\end{array}$ & Roasted then eaten \\
\hline 11 & Ampelocissus latifolia Planch. & Vitaceae & Ban angur & Leaves & As vegetable \\
\hline 12 & Andographis paniculata & Acanthaceae & Kalmegh & Leaves & Fresh dry leaves \\
\hline 13 & Antidesma diandrum Roxb. & Euphorbiaceae & Matha arak & Leaves & $\begin{array}{l}\text { Young leaves are used in curry and } \\
\text { as vegetable }\end{array}$ \\
\hline 14 & Averrhoe carambola L. & Averrhoaceae & Kaamrakh & Leaves & Dry leaves \\
\hline 15 & Azadirachta indica & Meliaceae & Neem & Leaves & Dry fresh leaves \\
\hline 16 & Bacopa monnieri & Scrophulariaceae & Brahmi & Leaves & Fresh leaves \\
\hline 17 & Basella rubra L. & Basellaceae & Poi sag & Leaves & $\begin{array}{l}\text { Stem and leaves are used to } \\
\text { prepare curry }\end{array}$ \\
\hline 18 & Bauhinia purpurea L. & Caesalpiniaceae & Singara & Leaves & $\begin{array}{l}\text { Young shoots leaves are cooked as } \\
\text { curry or fried }\end{array}$ \\
\hline 19 & Bauhinia retusa Roxb. & Caesalpiniaceae & Laba & Leaves & $\begin{array}{l}\text { Young shoots leaves are cooked } \\
\text { as curry }\end{array}$ \\
\hline 20 & Beta vulgaris $\mathrm{L}$. & Chenopodiaceae & Sakarkand & Leaves & As vegetable \\
\hline 21 & Biden pilosa & Asteraceae & Myna sag & Leaves & As vegetable \\
\hline 22 & Bigonia picta & Bigoniaceae & $\begin{array}{l}\text { Pakhanachatta } \\
\text { lundi ara }\end{array}$ & Leaves & Leaves are cooked as curry \\
\hline 23 & Boerhaavia diffusa Linn. & Nyctaginaceae & Khapra sag & Fresh leaves & Tender leaves fried/ roasted \\
\hline 24 & Butomopsis latifolia & Alismataceae & Lundi ara & Leaves & $\begin{array}{l}\text { Boiled then water is squeezed out } \\
\text { and then cooked }\end{array}$ \\
\hline 25 & Cassia occidentalis L. & Caesalpiniaceae & Barka chakonda & Leaves & Tender leaves are cooked \\
\hline 26 & Cassia tora $\mathrm{L}$. & Caesalpiniaceae & Chakoara & $\begin{array}{l}\text { Leaves and } \\
\text { seeds }\end{array}$ & Leaves are cooked \\
\hline 27 & Celosia argentea L. & Amaranthaceae & Siliari & Leaves & $\begin{array}{l}\text { Young leaves and shoots are } \\
\text { roasted }\end{array}$ \\
\hline 28 & Centella asiatica Linn. & Umbelliferae & Beng sag & Whole plant & $\begin{array}{l}\text { Leaves and young shoots are } \\
\text { roasted }\end{array}$ \\
\hline
\end{tabular}


Traditional Knowledge of Wild Edible Leaves

\begin{tabular}{|c|c|c|c|c|c|}
\hline 29 & Chenopodium album Linn. & Chenopodiaceae & Bhathua sag & Leaves & $\begin{array}{l}\text { Leaves and young shoots are fried/ } \\
\text { roasted }\end{array}$ \\
\hline 30 & Cissus adnata Roxb. & Vitaceae & Khatta sag & Leaves & Leaves cooked as vegetable. \\
\hline 32 & Cissus quadrangularis $\mathrm{L}$. & Vitaceae & Hadjor & Leaves & As vegetable \\
\hline 33 & Cleome gynandra L. & Capparidaceae & Sad hurhuria sag & Leaves & Leaves roasted \\
\hline 34 & Cleome monophylla L. & Capparidaceae & Hurhuria sag & Leaves & $\begin{array}{l}\text { Leaves and young shoots are } \\
\text { roasted }\end{array}$ \\
\hline 35 & Cleome vlscosa Linn. & Capparidaceae & Namkani & Young plant & $\begin{array}{l}\text { Leaves and young shoots are, fried/ } \\
\text { roasted }\end{array}$ \\
\hline 36 & Colocasia esculenta L. & Araceae & Pechki & Leaves & $\begin{array}{l}\text { Young tender leaves cut into small } \\
\text { piece, cooked with salt and chilly }\end{array}$ \\
\hline 37 & Commelina benghalensis Linn. & Commelinaceae & Kenna sag & Leaves & $\begin{array}{l}\text { Leaves and young shoots are fried/ } \\
\text { roasted }\end{array}$ \\
\hline 38 & Commelina erecta & Commelinaceae & Bas kena & Leaves & As vegetable \\
\hline 39 & Corchorus capsularis Linn. & Tiliaceae & Pat sag & Leaves & Tender leaves cooked \\
\hline 40 & Corchorus olitorius & Tiliaceae & Pat sag & Leaves & Tender leaves cooked \\
\hline 41 & Cordia dichotoma & Boraginaceae & Dhanul & Leaves & Tender leaves are cooked \\
\hline 42 & Cynotis cristata & Commelinaceae & & Leaves & As vegetable \\
\hline 43 & Eclipta alba & Asteraceae & Bhangara & Leaves & As vegetable \\
\hline 44 & Eclipta prostrate & Asteraceae & Bhrigraj & Leaves & Fresh leaves \\
\hline 45 & Enhydra fluctuans & Asteraceae & Muchri ara & Leaves & Chopped cooked/steamed \\
\hline 46 & Enhydra fluctuans Lour. & Asteraceae & Nunga sag & Leaves & As vegetable \\
\hline 47 & Eryngium foetidum & Apiaceae & Kanta dhania & Leaves & Adds flavour \\
\hline 48 & Euphobia hirta & Euphorbiaceae & Marang dudhi & Leaves & Tender leaves are cooked \\
\hline 49 & Ficus geniculata Kurz. & Moraceae & Putkal & Leaves & $\begin{array}{l}\text { Young leaves cooked. Pickle is also } \\
\text { made }\end{array}$ \\
\hline 50 & Ficus infectoria Roxb. & Moraceae & Phutkal & Leaves & $\begin{array}{l}\text { Young leaves cooked. Pickle is also } \\
\text { made. }\end{array}$ \\
\hline 51 & Gymnema sylvestris R.Br. & Asclepiadaceae & Gurmar & Leaves & Fresh leaves \\
\hline 52 & Hygrophila auriculata & Acanthaceae & Koila ara & Leaves & Cooked/Steamed and eaten \\
\hline 53 & Impatiens balsamina L. & Balsaminaceae & Murga phul & Leaves & As vegetable \\
\hline 54 & Ipomoea aquatic & Convolvulaceae & Kalmi & Leaves & Leaves cooked \\
\hline 55 & Leea macrophylla & Leeaceae & Hathi kana & Leaves & As vegetable \\
\hline 56 & Leucas aspera Spreng. & Labiatae & Guma & Tender leaves & Leaves taken as food \\
\hline 57 & Leucas cephalotes Spreng. & Labiatae & Choti guma & Tender leaves & Leaves roasted \\
\hline 58 & Limnophila aromatica & Scrophulariaceae & Lasodh & $\begin{array}{l}\text { Tender leaves } \\
\text { and shoots }\end{array}$ & $\begin{array}{l}\text { Cooked/Steamed Chatni is also } \\
\text { prepared }\end{array}$ \\
\hline 59 & Limnophila confirta Benth. & Scrophulariaceae & Muchari & $\begin{array}{l}\text { Tender Leaves } \\
\text { and shoots }\end{array}$ & $\begin{array}{l}\text { Leaves and young shoots are } \\
\text { roasted }\end{array}$ \\
\hline 60 & Limnophila gratioloids R.Br. & Scrophulariaceae & Kado sag & $\begin{array}{l}\text { Tender leaves } \\
\text { and shoots }\end{array}$ & $\begin{array}{l}\text { Cooked/Steamed and Chatni is also } \\
\text { prepared }\end{array}$ \\
\hline 61 & Limnophila rugosa & Scrophulariaceae & Lasodh Ara & $\begin{array}{l}\text { Tender leaves } \\
\text { and shoots }\end{array}$ & $\begin{array}{l}\text { Cooked/Steamed and Chatni is also } \\
\text { prepared. Have essence of unripe } \\
\text { mango. }\end{array}$ \\
\hline 62 & Lobelia alsinoides & Companulaceae & Bari ara & $\begin{array}{l}\text { Tender leaves } \\
\text { and shoots }\end{array}$ & $\begin{array}{l}\text { Cooked/Steamed, often cooked in } \\
\text { curry. }\end{array}$ \\
\hline 63 & Ludwigia adseendens & Onagraceae & Machli sag & Leaves & As vegetable \\
\hline 64 & Ludwigia octovalvis & Onagraceae & Machli sag & Leaves & As vegetable \\
\hline 65 & Marsilia minuta L. & Marsiliaceae & Sunsunia & Leaves & Tender leaves roasted \\
\hline 66 & Melochia corchorifolia Linn. & Sterculiaceae & Susuni & Leaves & Leaves cooked \\
\hline 67 & Mentha piperta & Lamiaceae & Pipermint & Leaves & As flavor \\
\hline 68 & Mentha spicata & Lamiaceae & Pudina & Leaves & As chatni \\
\hline 69 & Monochoria vaginalis & Pontederiaceae & Lochkor ara & Leaves & Cooked/Steamed \\
\hline 70 & Moringa oleifera & Moringaceae & Munga sag & Leaves & Leaves frying or roasting \\
\hline
\end{tabular}

Cont... 


\begin{tabular}{|c|c|c|c|c|c|}
\hline & & & & & \\
\hline & ivyciamitries arooristis & oleaceae & Harsingar & Leaves & rresh leaves \\
\hline 72 & Oxalis corniculata Linn. & Oxilidaceae & Netho sag & Leaves & Leaves fried and taken \\
\hline 73 & Oxalis corymbosa Linn. & Oxilidaceae & Tandi chatom ara & Leaves & Leaves are fried and taken \\
\hline 74 & Paderia foetida & Rubiaceae & Gandhraj & Leaves & Fresh leaves \\
\hline 75 & Pergularia daemia Forssk. & Asclepiadaceae & Mausi sag & Leaves & Cooked as vegetable \\
\hline 76 & Phylanthes nuriri & Euphorbiaceae & Bhumi awla & Leaves & Fresh leaves \\
\hline 77 & Pringlea antiscorbutica & & & & \\
\hline 77 & Piper longum & Piperaceae & Pipli & Leaves & Fresh leaves \\
\hline 78 & Polygonum barbatum L. & polygonaceae & Sake sag & Leaves & Young plants are cooked \\
\hline 79 & Polygonum glabrum Willd. & polygonaceae & Sauri arak & Leaves & Young plants are cooked \\
\hline 80 & Polygonum plebejum R.Br. & polygonaceae & Chimti sag & Leaves & Young plants are cooked \\
\hline 81 & Portulaca oleracea Linn. & Portulacaceae & Golgala & Young Plant & Tender leaves roasted \\
\hline 82 & Portulaca quadrifida Linn. & Portulacaceae & Noni sag & Young Plant & Tender leaves roasted \\
\hline 83 & Rumex vesicarius $\mathrm{L}$. & polygonaceae & Tissa palak & Leaves & Leaves are cooked \\
\hline 84 & Rungia parviflora Nees. & Acanthaceae & Kawoa sag & Young Plant & Tender leaves cooked \\
\hline 85 & Sagittaria sagittifolia L. & Alismataceae & Luchkor & Leaves & $\begin{array}{l}\text { Boiled then water is squeezed out } \\
\text { and then cooked }\end{array}$ \\
\hline 86 & Scoparia dilcis L. & Scrophulariaceae & Van dhania & Young plant & Adds flavour \\
\hline 87 & Trianthema decandra Linn. & Aizoaceae & Purni & Tender leaves & Leaves fried \\
\hline 88 & Tridax procumbence & Asteraceae & Jharmakhan & Leaves & A vegetables \\
\hline 89 & Vangueira spinosa roxb. & Rubiaceae & Sarla kanta & Leaves & As vegetable \\
\hline 90 & Dryopteris cochleata & Pteridaceae & Machli sag & Leaves & As vegetable \\
\hline
\end{tabular}

are bipinnate and stipulate. The inflorescence is cymose head and flowers are actinomorphic small. The calyx and corolla are valvate while petals are connate. Interestingly, the stamens number varies from 4 to many and fruit are legume. On the other hand, the plant belonging to family Tiliaceae are generally trees or rarely herbs comprise of 50 genera and 450 species which may be characterized by the presence of branched or stellate hairs. The leaves are simple and alternate, stipules are present. The flowers are actinomorphic and always bisexual (Plate 1). The reported plants do not have any authentic herbarium submitted to Department in current study.

The graphical presentation showed the highest percentage of leaves consumption in comparison to other plant parts (Fig. 2). The wild edible leafy vegetables are enumerated in Table 1, in which plants are arranged alphabetically with their local names and parts used method of consumption. The fundamental biological process of leafy vegetables used for the survival of the living beings. On the basis of knowledge gained through successive generations and experience, food habits have been developed (Richards, 1948). The Table 1 showed that the wild edible leaves are seasonable throughout the year. Commonly called 'Phutkal' is very popular in Chhattisgarh. It is not only popular vegetable but its pickle is prepared which is very common in most of the households of tribal and local inhabitants. In India leafy vegetables are commonly called sag includes Muchari, Khapra sag, Beng, Sunsunia, Koinar leaves, Bathua and Chimti are common leafy vegetables. These leaves are dried and used in off season; called Sukti, Green leafy vegetables are boiled the dried and then stored. Such dried food stuffs are cooked with starch (Gupta, 1974; Tewari and Sharma, 1989). Hence, Traditional leafy crops are important fresh crops during the rainy season. They are especially important in dried form during winter and spring seasons (Jain and Tiwari, 2012).

The most important thing about these vegetable species is that in spite of most being seasonal, these are consumed throughout the year. Most of these wild leaves are consumed after cooking, roasting or frying. Local tribal's get the leaf dried and store them to be used in off season (Bhatt and Bhargava, 2006). In the local market, one can find the fresh leafy vegetables as well as dried leaves. Thus, these wild leafy vegetables are the chief source of nutrients such as proteins, carbohydrates; fat, vitamins and minerals for tribal peoples (Dwivedi, 2007). The communication deals with the native uses of ethnobotanical species identification and chemical analyses of different edible parts of wild plant species consumed by the local people inhabiting in the tribal areas of Bilaspur district, situated in the eastern part of Chhattisgarh state of India. Total seventy wild edible plant species were identified and recorded. Out of seventy plants species 25 are chemically analyzed and presented in this paper. The methods employed in this study were designed with the purpose of providing baseline information on the wild edible plant species in local system through surveys (field visits) and there nutritional potential through chemical analysis of different edible parts. Plants were collected, photographed, identified and voucher specimens prepared for the herbarium. The proximate nutritional composition, ash, moisture, carbohydrate, crude protein, crude fat, crude fiber, energy and iron were determined (Vishwakarma and Dubey, 2011).

\section{Conclusion}

Thus it was concluded that wild edible leaves are the solution to solve the poverty and socio-economic condition of the tribal and local inhabitants of Chhattisgarh for their day to day food requirements. These are the nature's gift to the inhabitants of forests to fulfill their nutrition requirements. Overall these leafy vegetable seems to provide a great opportunity to the tribal peoples for their better livelihood. The utilization of different method may enhancing their production both in vitro and in vivo can manage the ecological biota of tribal people. 


\section{References}

Ahirwar, R.K. and Shakya, V.S. 2013. An ethnobotanical survey of some wild edible plants of Bijuri forest district Anuppur, Madhya Pradesh, Central India. International Journal of Science and Research 4: 614.

Bhatt, S.C. and Bhargava, G.K. 2006. Land and People of Indian states and Union Territories: Vol. 12, Kalpaz Publication, New Delhi.

Chauhan, D., Srivastava, A.K. and Patra, S. 2014. Diversity of leafy vegetables used by tribal peoples of Chattishgarh, India. International Journal of Agriculture and Food Science 3(4): 611-622.

Chowdhury, M. and Mukherjee, R. 2012. Wild edible plants consumed by local communities of Maldah district of West Bengal, India. Indian Journal of Science and Research 3(2): 163-170.

Cooper, H.D., Spilane, C., Anishetty, N.M. and Griffee, P. 1966. Promoting the identification, conservation and use of wild plants for Food and Agriculture in the Mediterranian: The FAO Global Plan of Action, FAO, Rome.

Dwivedi, A.P. 2007. Forests the non-wood resources. International Book Distributors, Dhera Dun, pp. 352.

Ekka, N.S. and Ekka, A. 2016. Wild Edible plants Used by Tribals of Northeast Chhattisgarh (Part-I), India. Research Journal of Recent Sciences 5: 127-131.

Grivetti, L.E. and Ogle, B.M. 2000. Value of traditional foods in meeting macro- and micro-nutrient needs: The wild plant connection. Nutrition Research Reviews 13: 31-46.

Gupta, P. 1974. Tribes of Chotanagpur Plateau: An ethno-nutrition and pharmacological cross-section. Bihar Tribal Welfare and Research Institute, Govt. of Bihar, Welfare Department, Ranchi.

Jain A.K. and Tiwari P. 2012. Nutritional value of some traditional edible plants used by tribal communities during emergency with reference to Central India. Indian Journal of Traditional Knowledge 111: 51-57.
Lal, S., Gupta, D.K., Dewangan, B., Koreti, D., Sunanda, Prakash, K., Lal, M., Kumar, M., Dewangan, B., Dewangan, S., Pushpanjali, Thakur, B., Thalendra, Kumar, D. Tara, Thakur, K., Sahu, P., Kunali and Yadav, S. 2017. Some edible plants of Bhoramdeo Wild Life Sanctuary Kabirdham, Chattisgarh, India. Indian Journal of Scientific Research 13(2): 236-247.

Mishra, S. and Mishra, M.K. 2013. Leafy vegetable Plants of South Odisha, India, International Journal of Agriculture and Food Science 3(4): 131-137.

Ogle, B.M. 2001. Wild vegetables and micronutrient nutrition: Studies on the significance of wild vegetables in women diets in Vietnam. Comprehensive Summaries of Uppsala, Dissertations from the Faculty of Medicine, Uppsala University, pp. 1-55.

Ogle, B.M., Dung, N.N.X., Do, T.T. and Hambraeus, L. 2001. The contribution of wild vegetables to micronutrient intakes among women: An example from the Mekong Delta, Vietnam. Ecology of Food and Nutrition 40: 159-184.

Ogle, B.M., Tuyet, H.T., Duyet, H.N. and Dung, N.N.X. 2003. Food, feed or medicine: The multiple functions of edible wild plants in Vietnam. Economic Botany 571: 103-117.

Richards, A.I. 1948. Hunger and work in a savage Tribe: A functional study of nutrition among the southern Bantu. The Free Press, Glencoe, Illinois.

Sharma, M. and Sharma, R.P. 2017. Diversity of edible wild plants of Pendra road forest region of Chhattisarh. International Journal of Advanced Educational Research 2(4): 24-28.

Tewari, P.D. and Sharma, A.M. 1989. Tribal ecosystem and malnutrition in India: Proceedings of the National Seminar; Northern Book Centre, New Delhi.

Vishwakarma, K.L. and Dubey, V. 2011. Nutritional analysis of indigenous wild edible herbs used in eastern Chhattisgarh, India. Emirates Journal of Food and Agriculture 23(6): 554-560. 